\title{
Both Sides of CSR Practice: A Case from Oil and Gas Industry in Kazakhstan
}

\author{
Gulzhan Buldybayeva
}

Abai Kazakh National Pedagogical University

Bukhar-Zhyrau 23, 9, Almaty, Kazakhstan

\begin{abstract}
Given article covers some special aspects of Corporate Social Responsibility in the oil and gas industry of Kazakhstan. The research deals with the analisys of activities of Kazakhstani multinational companies similarly to other transnational corporations of exploration and production industry in developing countries, which belongs to good or the darker side of the responsible acts. Recommendation demonstrating with a case study how to develop a better strategy for corporate social responsibility which helps leading Kazakh oil and gas joint venture company to avoid the possible occurrence of the CSR Dark side is presented in this article.
\end{abstract}

Keywords: corporate social responsibility; developing countries; oil and gas industry, exploration and production; case study; Dark side

\section{Introduction}

Since the 1990s, the concept of corporate social responsibility (CSR) has gained strong popularity within the business industry of developing countries, saying and doing both theoretically and practically. In the beginning, the concept had an Anglo-American feature based on "stakeholder economy” by British Prime Minister Tony Blair in 1996 [10] and followed by first, the US view of market driven operation of business, and later became, the general use of social and environmental aspects of business operations. Porter and Kramer [36] were leading proponents of the view that different types of social issues linked to core business of the company: generic social issues, value chain social impacts, and social dimensions of competitive context [5]. These thoughts were spread with dizzy quickness towards developing countries of the world generating an endless debate on the concept and meaning without any chance for final consensus on it. There are at least two explanations of this lack of consensus. Ghosal in 2005 [14]. First of all there is an argument that CSR concept is only a social marketing idea, a general speech from corporations which take care of their public image but avoid making any important changes, or even worse, it is managed by business 
people who have no moral responsibility for the business and the community. The publication of Berthoil and Sobczak [6] raises this issue, the term ,corporate social responsibility" doesn't necessarily have the same meaning in culturally different places (countries, regions, continents) of the Globe. The Asian and European traditions are different from those of the Anglo-American.

„Is corporate social responsibility the privilege of developed market economies?"question has been proposed by Koleva and her co-authors [23]. The answer is evidently: it is not a privilege of dedicated developed countries and there is less evidence of its existence in other geographical areas. Due to economic system change, the horrible amount of foreign direct investments to these regions, and the dominant presence of multi- and transnational companies (MNCs and TNCs) have resulted in the manifestation of CSR concepts in the new market economies including the (new) countries of Central and Eastern Europe and Kazakhstan (a state of former Soviet Union).

CSR practice has a great developing potential in Kazakhstan. This issue is important not only for the government but for the multinational companies which run business in Kazakhstan. What's important to distinguish today is that the companies see CSR as an obligation before the government of the country they are bringing their business into. Of course it is understandable that the giant multinationals enter the third world countries for reasons other than charity, however they must change their attitude towards CSR. The emergence of CSR concept in domestic and joint venture and multinational companies of the developing countries offer different implications of post-socialist compromises related to CSR. The convergent features of CSR in these countries have partly been explainable by post-socialist traditions. Different levels of interaction of actors produces very different CSR models, like hierarchical, participative, minimalist, endogenous, exogenous or hybrid [23]. The old general rule of management studies, „no one best way”, is succeeding in this respect, too. The result is that CSR models and protocols have a big selection: the company managers, researchers can have a very broad variety of practices for application and field for research, for preparing case studies.

Traditional approaches to corporate social responsibility describe it as a contribution to society of businesses, apart from economic sector, industry, products or services the company operates and delivers. In every case the CSR wants to say something to the community about the operation of the company. In this regard such industries where the „content of saying” [33] has a long-term dimension, on the one hand, and the number of addressed people is extremely large, on the other hand, they are placed in distinguished position. The exploration and production industries have to be classed among this group of industries in different parts of the world. This business field is a very common target of CSR researches and publications. 
The Oil and Gas Industry nowadays is the most robust actor of the exploration and production industry. The responsibility of owners, managers and the employees of these firms, MNCs, TNCs for the present and for the future, is huge. The deal with the topic of CSR in the developing countries is such that, corporations in the oil and gas industry propounds some delicate questions. CSR is a positive concept, a very nice result of positive thinking of mankind.

However, the sources and international practice has demonstrated many losses and mistakes, misconceptions, conspiracy of silence and scandals (e. g. Exxon Valdez, Mexico Gulf accident, Bonga Onga exploration area disaster). Behind these events, very often the bad CSR solutions are hidden. It is called the other side or the Dark Side of CSR, summarized by Baghi at al. [4]. Since, the technical development of this industry is not able to preclude the uncertainties, the CSR programs and its communication bear almost all the responsibility to avoid the occurrence of the dark side of CSR.

\section{Overview of the Oil and Gas Industry in Kazakhstan}

Oil and gas sector of Kazakhstan is the most dynamic sector of its economy. It provides a significant portion of national GDP. Since independence from Soviet rule in 1991, Kazakhstan has received more than 18 bln. US\$ in 2010 of foreign direct investment - the highest per capita indicator in the former Eastern Bloc. The exploration of the largest oil field in the world, Kashagan, will make Kazakhstan one of the major producers of hydrocarbons not only on the regional, but also on the international level. Production of crude oil and natural gas condensate from the oil and gas basins of Kazakhstan amounted to 79.5 million tons in 2010, up 4\% from the production in 2009. Kazakhstan raised oil and gas condensate exports to 72 million tons in 2010, which makes almost $91 \%$ of the produced oil in 2010. Gas production in Kazakhstan in 2010 amounted to 37.4 billion cubic meters. At the moment Kazakhstani gas is supplied to Russia only, however it is said that another independent pipeline to be built in the direction of China in 2013. Expected amount of Kazakh gas to be supplied to China is 30 billion cubic meters per year [50].

On the territory of the Republic of Kazakhstan 202 oil and gas fields are located. They are placed between the 6 out of 14 regions of the country. They are Aktobe, Atyrau, Western-Kazakhstan, Kyzylorda, Karaganda and Mangistau regions. The production is conducted from the 55 fields, the main ones are Tengiz and Karachaganak [43].

Today the oil and gas sector is represented by numerous companies. The largest national petroleum company is "Kazmunaigas" and it is engaged in a full cycle 
from exploration and production to the petroleum stations around Kazakhstan. There are many of the worlds majors involved in the development of three giant fields such as Tengiz, Karachaganak and Kashagan. Chevron holds important stakes in Tengiz and Karachaganak and a number of different international Oil Companies (primarily Chinese) also have significant stakes in the large Kazakh onshore fields. Other companies invested in the area include ENI, BG, Total, LUKoil, Shell, ExxonMobil, ConocoPhilips and Inpex [13].

The oil and gas industry is usually divided into three major sectors: upstream, midstream and downstream. The upstream segment of the industry, often called exploration \& production, is traditionally what comes to mind when people think of the oil and gas industry. Companies will search prospective areas for potential reserves of oil and gas and perform geological tests called seismic tests, to determine the size and composition of the resource. Initial wells are often drilled to "explore" the basin, and if satisfied with results, a company will enter the production phase to extract the hydrocarbons.

Often coupled with the downstream segment, the midstream sector involves the transportation, storage and marketing of various oil and gas products. Depending on the commodity and distance covered, transportation options can vary from small connector pipelines to massive cargo ships making trans-ocean crossings. While most oil can be transported in its current state, natural gas must be either compressed or liquefied for transport. The midstream sector also includes the storage of oil and natural gas, which balances the fluctuations between supply and demand and helps ensure a secure supply of energy products.

The downstream sector involves the refining and processing of hydrocarbons into usable products such as gasoline, jet fuel and diesel. Refining is required since "raw" hydrocarbons extracted from the ground are rarely useful in their natural form. The refining process is a complex chemical process that helps separate the hundreds of hydrocarbon molecules into useful forms. Petrochemical plants also break down hydrocarbons into chemical compounds that are used to create a myriad of products ranging from plastics to pharmaceuticals [1]. Through the period of independence of Kazakhstan the oil and gas sector has made a significant growth. In 1999, Kazakhstan has celebrated 100 year anniversary of the oil and gas sector. The first oil has been produced in 1899 in the field called Karashagul. Passing this uneasy path, Kazakh oil and gas sector makes a significant contribution to the economic, social and cultural development of the country. Only in the last decade Kazakhstan has doubled its oil production [54]. By the level of oil production Kazakhstan is amongst the 20 producers of the world's oil and gas industry (With future development of the Kashagan field Kazakhstan will enter the top five oil-producing companies in the world).

During this short period the oil and gas sector along with the national economy has experienced the difficulties of transition and market reforms. The Kazakh economy lacked sufficient financial and technical capabilities to develop the 
gigantic oil fields such as Tengiz and Kashagan. That's when it was decided to attract foreign investors, companies that have the experience and the finances necessary to develop these fields. However, along with the positive aspects of attracting foreign investments we must mention the drawbacks of the given policy. Often, foreign companies forget about their obligations mentioned in the contracts, they become unsympathetic to the problems of the region they enter with their business. Companies do not use the local labour force; pay no attention to the social sphere of the region.

In order to come out of the dependency on foreign investments, Kazakhstan is coming out with its own investment opportunities; domestic investors are willing to invest their money into promising projects. The share of foreign capital has been reduced to half of the total investment. This means that this country has emerged strongly and is capable to finance major projects on its own. All of this suggests the need to change the strategy of the oil and gas sector of Kazakhstan. It is important, without compromising the interests of foreign investors, to line up our national interests, the situation in the oil and gas sector.

The oil and gas industry is capable to support all the monetary fund into Kazakh treasury, it contributes to the development of different fields of economy, and of course to the standards of living, because the development of oil and gas industry affects the economic rise not only the spheres directly related to the oil and gas industry. Production, transportation of large volumes of oil and gas, during the certain economic policy, develop grounds for developing domestic energy, chemistry, petroleum chemistry, telecommunication, transportation, construction of roads and infrastructure sectors. All these economic sectors contribute to the development of science and innovative technology. That is why the Republic of Kazakhstan connects all its future plans and hopes to the oil and gas industry. In order to increase the effective use of oil and gas resources Kazakhstan has to be determined to extract maximum income from the export of oil and gas without affecting the stable development of the oil and gas industry.

The world has not yet come to the point of stop using the oil and gas. The petroleum Era has not come to its finish. The market is still going strong stated a world wide well known expert at this industry Tippee [44].

\section{Methodology of the Study}

Case study methodology has been applied for the research. This method is a well known effective tool to represent and analyze real business activities and projects as well as the social movements from early at entering social science researches to business life [42], [15]. This methodology is frequently used in the oil and gas industry with different objectives [26], [32]. The firstly quoted case about the 
Norwegian industry is partly applicable for the Kazakh oil and gas companies. The study mainly focused on the analysis of CSR activities and performances at the Tengizchevroil. To meet the need of the objectives of the study, data were collected and analysed from the secondary sources of the sample company in Kazakhstan. Previously, an extensive desk and library work was conducted to get a clear idea about the concept of corporate social responsibility in general and especially within the exploration and production industry with an outlook into the developing countries. The semi-structured interviews with competent managers of the company and different leaders of community assisted us to understand the inner main goals and ideas of the companies on the one hand. The daily practice of CSR, at the Tengizchevroil joint venture company on the other hand. The investigation of CSR reports of Chevron Corporation in the previous years and in addition TCO gave useful information regarding current joint community development programs within the Caspian region of Kazakhstan. The proposed framework can support practitioners in the oil and gas industry (and other industries) to develop their CSR system.

\section{TCO Case Study}

\subsection{Good (Positive) Side of CSR}

Tengizchevroil (TCO) - joint Kazakh-American Corporation a leading exploration, development, production and marketing of petroleum and related products. TCO is the largest oil producer of Kazakhstan's oil and gas sector. The Tengiz oil field was first discovered in 1979 and is one of the deepest and largest oil fields in the world located in the Western part of Kazakhstan. In April of 1993 with the signing of an agreement between the Government of the Republic of Kazakhstan and the "Chevron" Corporation the Tengizchevroil has been created. Today, the shareholders of the Tengizchevroil are: Chevron - 50\%, KazMunaiGas (Kazakh National oil company) - 20\%, ExxonMobil - 25\%, and LukArco - 5\%. The duration of an agreement is 40 years [35].

From the day Chevron and the Government of the Republic of Kazakhstan signed an agreement; they have undertaken a responsibility before the community they where they are acting. "We strive to work so that the result of our work was a real improvement in people's life" [35]. Throughout its stay in Kazakhstan, TCO has shown a great respect towards the agreement and has developed several social investment programs which were included in its Annual Corporate Social Responsibility Report. The terms of corporate social responsibility is well known within the interviewed managers of TCO. (The sample was relatively small, 11 persons who are working at the company in "CSR-related" positions.) Among the 
tested definitions had a first priority that the CSR is ,the CSR covers the relationship between corporation (or other large organization) and the societies with which they interact. CSR also includes the responsibilities that are inherent on both side of these relationships. CSR defines society in its widest sense and on many levels, to include all stakeholders and constituent groups that maintain an ongoing interest in the organization's operation" $[19,18]$. The definition from the early history of CSR concept had been accepted as basic point of understanding the corporate social responsibility at TCO. The CSR Reporting is a daily practice of existence of the TCO model and the majority of these managers are personally involved in report writing process. From the major CSR programs at company was mostly mentioned two of the TCO applications. They are the Egilik and the SIP. Next paragraphs of the paper will highlight the results of these prominent programs. Both of these programs were mentioned as an output of positive side of the CSR operation at TCO.

\subsubsection{Egilik Voluntary Program in Atyrau Oblast}

At the start of Tengizchevroil joint venture in 1993, the company created a fiveyear, \$50 million dollar program called Atyrau Bonus Fund. At that time, TCO developed a tradition of working collaboratively with the Atyrau Oblast Akimat leadership to choose social infrastructure projects in Atyrau Oblast to be funded with Tengizchevroil funds.

In 1999, TCO developed a first voluntary program Egilik (Kazakh for benefit) program to succeed the Atyrau Bonus program. It began in the year 2000 with a $\$ 4$ million budget, growing steadily until 2003 when the budget was increased to $\$ 8$ million for three years and then again increased to $\$ 12$ million for another three year period.

Today, the budget is $\$ 20$ million per year. The majority of funds are currently dedicated to replacing the water system in Kulsary, the nearest population center to the Tengiz field and home to many TCO employees and contractors. This project will take three years and compliments one of the TCO Community Investment Program key focus areas; health. TCO health and social impact assessment studies sites that Kulsary water quality and water service is undependable and low. In 2008, Tengizchevroil was bestowed the Silver Paryz Award for another Egilik project in Kulsary, the vocational school built to educate the future of the oil industry.

Over the life of the program, TCO has funded various social infrastructure projects for water systems. By the end of 2011, TCO have invested \$185 million in the Egilik and Atyrau Bonus programs since 1993. 


\subsubsection{The SIP is to Improve the Quality of life of Employees}

The Social Investments Program (SIP) has been an initiation of TCO in the development of the social sphere of the region with an annual budget of $\$ 1$ million dollars. As the result of recent organizational decisions, TCO improved social investments program, which meets the public and industry needs and goals. The company has created a Council on Social Investments, which consists of representatives from different departments of the company, whose competence includes the distribution of the SIP budget. The Council also developed a philosophy and strategy of social investment, changing the vector from simple charity to target actions by which the urgent problems are resolved, and important social goals are achieved with priority to Atyrau region and TCO.

The aim of the company is to find direct connection of the projects necessary to the public without missing its own interests. Thus, the priorities have been identified, priorities in education, supply of drinking water, environmental protection, as well as the provision of quality health care.

When it comes to education, the company aims to educate its own staff for the further development in order to invoke them in the strategy of nationalizing the staff. To accomplish this TCO has a strong training and development plan for its employees. TCO has spent over 28 million USD $\$$ for its training and development plan over the 9 year period. Every year the company trains the employees at training courses abroad.

Nationalization of the staff is a practice that all the TNCs use when they enter developing countries. In TCO is already taking place, today it is almost $85 \%$ of the staff are local employees compared to 1993 when it was only 50\%. TCO believes in taking care of its own, so they offer great housing projects for its employees, support for employees' families and healthcare. The most popular benefit among employees is the housing loan program. TCO has invested over 32 million USD \$. This is done in order to improve the quality of life of employees.

Continue with educational program, TCO has invested on scholarship program. It grants 70 scholarships a year to high school graduates, four of them are granted to gifted children from the Atyrau region and rest is split amongst the children of the employees. The company also provides internships; about 3000 students per year are able to enter the program.

TCO has invested over 450 million USD \$ in social projects, which include building hospitals, schools also funded improvements of roads, water and etc.

Once again, TCO has become a silver winner of 2008 Paryz honour award for corporate social responsibility. This award is a creation of the President of the Republic of Kazakhstan Nursultan Nazarbayev, to recognize all the good the companies do for the community where they operate [39]. 


\subsection{The Dark Side of CSR and How to Avoid It}

The history of Corporate Social Responsibility concept proves, CSR has the potential both positive and negative impacts [4], [7], [28]. The negative impacts have been said to be the dark side of this management concept. The appearance of the dark side is especially dangerous within environment - in the industries such as oil and gas mainly in developing countries of the world emphasises Belal [5], and the 2012's report of the WTO [51]. The social and environmental impact (health and safety risks, large-scale air pollution) of the oil and gas industry affects the image or reputation of the company [46]. Therefore, building a sustainable corporate image is important to the industry. When one company suffers from image loss, the industry in total can be affected. In certain respect the situation seems to be similar to the one that has been outlined by the Hungarian edition of Kotler and Lee book about the CSR practice of Hungarian Oil Company (MOL) [24]. Oil activities very often have caused heavy damages to the environment more than in one occasion. The oil production process consists of upstream and downstream operations that include activities such as drilling, well completion, well testing, oil treatment and transportation through pipelines to consumers. Lands, farms, animals, forests and seas are affected from extensive growth of oil and gas production, transportation and distribution. The impacts of these processes may be partly natural, partly social. The natural consequences are perceptible and tangible (like air pollution, low farm production, polluted water). However, social impacts seem to be indirect. Negative impacts of CSR are illustrated by these social effects on local communities. The oil and gas industry show very broad examples from the developing world. The firm's relationship with their community via operation and community development programs hide many possibilities of conflicts. Local individuals and groups are fighting for donations of international oil companies, for services and infrastructure provided by MNC'S, community leaders try to exclude the other actors of community.

Originating from aspirations of these countries new concepts for tailoring CSR to the demand of developing countries are continually emerging. For example Ite suggests that the oil TNCs are making considerable contribution to community development in the Niger Delta in Africa that reflects the changes to new CSR model [21]. Idemudia says: „A South-centered CSR perspective has both been instrumental to the maturation of contemporary CSR agenda as well as generating fresh critical insights into the limits and strengths of CSR initiatives in developing countries" [20,11]. The black side of CSR should successfully be counterbalanced with other new models that had been published, like Global Memorandum of Understanding (GMoU). The implementation of GMoU is Chevron, one of the main partner of this initiative, shows a good example of community development as a part of modern CSR concept [21]. Chevron model of the GMoU represents a radical departure from the past, from the earlier models in terms of benefits, both 
to the communities and company. These experiences are applicable for other Chevron investments like Tengizchevroil in Kazakhstan.

Similar outcome of new type of corporate social responsibility programs has developed for the oil and gas industry in India under the scheme of Oil and Natural Gas Commission. Oil companies in India have manifested CSR in a variety of ways, most of which have been quite innovative in the field of community development, promoting excellence, environmental management, preserving national heritage and other CSR-related issues [37].

As it was presented in earlier part of this paper the CSR practice is a new challenge for Kazakh Big Firms. It raises a question: how could be interpret both sides of this business phenomenon? Are there symptoms of black side? Is there any chance for corporations to avoid them? First of all, it must be stated that the Kazakh Presidency and Government do everything to avoid other (dark) side of CSR practice:

- Kazakhstan joined the EITI (The Extractive Industries Transparency Initiative) in October 2005 [51]. Consequently, Kazakhstani Government has accepted the multi-stakeholder initiative, involving business, government, international organizations, promoting transparency and accountability of the revenues from exploration and production industries;

- the national legislation has guaranteed protection for all business actors (domestic and international investors, local producers, labour force), at the same time the guarantee has been expanded to direction of national security, defence, environmental safety, healthcare as has pointed out Yerkebulanov and Saginova [52].

- the other special project within the oil and gas industry (e.g. Caspian Revenue Watch) that started for the whole geographical region, is to reduce the dark side of industrialization [18]. However, the initiative for the community development conducting by the Open Society Institute finally was not totally successful [45], the main idea of transparency and social responsibility has been converted into the daily business in Kazakhstan;

- due to many reasons, in Kazakhstan the Transnational Oil Companies have not been the target of negative or anti-corporate campaigns, as in the case of other developing countries (mainly in Africa and Latin-America). Many times in these countries the poor CSR performance of transnational oil corporations and the inadequate CSR package has overshadowed the benefits of good initiatives [5], [31], [38], [46]. One of the most famous researchers of this topic Michael, J. Watts pointed out that one and a half decades ago, that " ... the current political economy of the oil industry, new bodies of research on the relations between oil and human rights violations, which include case studies of the human rights records of transnational and joint-venture oil operations" $[49,375]$. 
Taking into consideration many reasons, naturally to have a declared legal system, to join international movement and to be part of high-sounding projects - it is not enough to avoid the impending dangers and mistakes either for the society or for the companies. It is necessary to take permanent, significant efforts for the sake of averting CSR aspects that want to be effective. The focus for business community investment tends to be on some of the further issues around health, the environment and economic development, and much more focus on building or supporting civil society in Kazakhstan [16], [40], [46].

\subsection{New Challenges for Tengizchevroil: Recommendations}

Learning from company history and experiences of CSR practice conducting interviews on the field with combination of external (domestic and international/foreign) knowledge, the Tengizchevroil faces new challenges. The creation of a sustainable corporate image as an essential part of a proactive strategy and core value creation is addressing series of potential challenges in the near future. Eventually, these challenges can use this list of recommendations: how the corporate social responsibility system at TCO should be developed in five areas.

\section{Development of relation with the Government:}

- because there is the absence of agreed definition and clear common understanding of CSR among the state, business and society, Tengizchevroil as a transnational company has to be pioneer for this clarification process which is badly needed.

- effective implementation of the Government CSR Strategy desires a powerful support from leading corporations such as TCO so that co-operation between the State and the Company should have been successful for long term. In light of the existing "Public Responsibility Deficit" [47,53] and the growing power and dominance of big corporations they are wearing more and more responsibility for supporting the Government that this deficit should be reduced. In creating attention focusing on the role of companies in public service provision - one of the best strategy for TCO.

- the requirement for "social investments" of the Company can pose a further challenge to a company's development of a business strategy that takes CSR as significant part of TCO's core business in Kazakhstan.

\section{Communication channels and priorities:}

- the Tengizchevroil is a massive business actor of Atyrau Oblast. The activity and voice of this company determines the economic and social life of many other actors (both organizations and private people). 
- the main issue of CSR communication is the reporting. CSR reporting has developed in quality and quantity since the first reports were published. To further explore this issue, the literature specifically focusing on The CSR reporting of the exploration and production industries such as oil and gas. For this industry, a special publication on reporting was published in 1999 by Sustainability [17]. At that time 50 companies were surveyed, 34 were publishing environmental reports. The oil and gas industry is active in this area, for the year $200580 \%$ of all companies from exploration and production industries produce reports on CSR activities - state the above mentioned German researchers. As a suggestion, another good methodology that is well known within the exploration and production industry is the GRI (Global Reporting Initiative) guidelines. This method was developed by one of the big consulting firms, KPMG [25].

Above listed initiatives are applicable to demonstrate CSR achievements within the sections of: vision and strategy of the company, profile of the company performance indicators and the economic, environmental and social perspective." They are the basic elements of a well-structured CSR reporting system. Although, Tengizchevroil constantly, year by year fulfills its liability with reporting, but it is mainly not more than a forced obligation. The challenge is for the TCO top management to work out a new mode of CSR reporting. The applicable model seems to be a „CSR information package” of Morsing [34], which ideally should address following key words:

- promise: show CSR as a shared concern - Invisible contribution but visible success in various fields

- $\quad$ proposition: link CSR to core business - direct link between business and safety/environment

- evidence: demonstrate organizational support - "we and our" stakeholders (partners and customers).

- results: demonstrate objective claims - High level of detail to increase credibility, sifting on various technology used by TCO.

\section{Improvement of relation to business environment and community:}

- the primary interest of TCO CSR practice is to keep solid relationship with its stakeholders from business environment. The stakeholder analysis could demonstrate elementary importance of local population. Concerning to this very evident fact, to improve the public relations in the given region of TCO operation represents high priority for corporate social responsibility process.

- as it was mentioned by the interviewed managers and the secondary sources, TCO supports many civil organizations in the Caspian, Atyrau Oblast [27]. Despite of flowering character of nonprofit and non-governmental sector in Kazakhstan, it is permanently facing new challenges [2], [19]. In newly published empirical study by Makhmutova and Akhmetova the lack of 
professional and skilled managers and qualified staff and volunteers within the sector has been pointed out [30]. According to the results of these studies the NGO sector and the powerful actors of the competitive sphere (e.g. from oil and gas industry) must be strong partners. (Good example is the success of Atyrau Bonus Fund.) The for- profits can have direct benefits if they utilize the social power of not- for-profits if they strengthen their efforts for leading community development, environment protection-oriented projects. For example (Green Line Buzz, EcoCenter, and especially the earlier demonstrated Egilik in Kazakh Caspian region) and big oil corporations (as the TCO is) have to be key players on this stage.

\section{Contribution to the community wellbeing:}

- this theme of community wellbeing represents a very attractive and challenging goal structure for TCO focusing on its involvement in the community. Following the findings of Cowper-Smith and Grosbois [11] by this concern at the Tengizchevroil the most popular initiative would be: supporting training and education possibilities for youth, donating arts and culture projects and events, supporting environmental education in local schools. All this should be offered on higher quality and quantity level.

- the internal context of community wellbeing relates to employees of the company. The annual average number of TCO's employees is about 15,000. They are aspiring for good working and living conditions and for healthy environment as citizens of Kazakhstan. The physical circumstances and even the mental conditions of workforce should have an important indicator of CSR construction of TCO. The corporate social responsibility agenda cannot ignore the personal feeling of company's people: they are the primary stakeholders of the organization.

\section{Communication and communication:}

There is a common feature of every CSR concept. Growing public demand for information regarding corporate social responsibility plans and actions using the most appropriate communication channel. Positive messages from the TCO to the society should beconveyed through such channels like:

- $\operatorname{logos}$

- short banners

- informational materials, presentations

- commercials and media advertisements

- independent reports on companies

- records of journalists
- publication of corporate reports

- CSR-award

- CSR-event

- CSR-webpage

- forums and blogs

- CSR-applications in social media

- publication of the code of ethics [3]. 
Understanding the local relevance of these possibilities, the communication is extremely needed, because the communication is "the soul of the CSR". The TCO has a very nice technical presentation of CSR on the company website, notwithstanding, shows lack of a well-constructed plan for communication of CSR actions. The recommendation regarding this statement has first priority: a correct plan for two different types of cases to be worked out. Firstly, the regular daily operation of CSR actions and processes. Following action such as distribution must take place, every stakeholder and group of community should be informed on how Tengizchevroil thinks about the corporate social responsibility and what it does for its success? Secondly, it is important to emphasize that communication of conflicts and handling of different conflict situations is also a part of CSR communication system [28], [48]. There are lot of possibilities of emerging conflicts at business operation of TCO. The predictable issues are:

- diverse expectations create tensions between ethical and economic interests and values. These two views are grounded historically contradictory, but the short history of Kazakh oil and gas industry was not able to offer effective mechanisms to cope with this paradox, yet. The time has arrived for working out a system of knowledge intensive professional business service model which is able to meet the needs of international CSR concepts argues for this concept the professors of University of Pécs Faculty of Economics and Business Katalin Dobrai and Ferenc Farkas who are privileged researchers of KIBS topic [12].

- the extractive industry is a dangerous one. The natural crises and disasters seem to be real dangers with non-predictable probability. The Kazakh society has to be sure that Tengizchevroil Co. would be able to handle this unforeseen situations and to save the people and the nature of Kazakhstan. That is the Complex Concept of Corporate Social Responsibility.

\section{Conclusions}

This paper has verified the relevance of corporate social responsibility application at one of the flagship company of Kazakh Oil and Gas Industry the Tengizchevroil. By the statistical data this industry offers a proper field for the concept in an international framework: In the 2013 ranking Global 100 Most Sustainable Companies have listed dozens of big corporations from energy sector; the trend is positive from the viewpoint of the energy sector in comparison with previous years (the representation of the sector was less); TCO, Chevron, over the six years invested approximately 1 billion US dollars in areas essential to sustainable communities, including health, education, and economic developmentCEO message published on the company's website [35].

Connecting to the strategy and activities of TCO, who launched 1 million \$ USD on Social Investment Program, and recently, Egilik the main subject of the delivered case study. These initiatives to be considerable starting-point to direction of advanced CSR system at Tengizchevroil. 
This kind of business such as Tengizchevroil plays a major role in creating wealth and innovations, supplying markets, and generating employment, while at the same time contributing to the community in which it operates. Society on the other hand is expected to provide environment where enterprises could develop and prosper, allowing investors to earn profits without fear of unfair actions from the government [53]. This general business hypothesis for this matter [29] was also proved with demonstrated case study.

It is important to note that the responsibility of the corporations to behave socially shall be spread on all companies, both local and foreign companies to avoid any discrimination.

Unsocial activities are penalized, and are grounds for very harsh sanctions starting from administrative fines the amount of which could be estimated in millions, temporary suspension of the petroleum activity in the country, and what worse is the permanent license and contract termination or even criminal liability of the managers of the company. Therefore, compliance with the law is the minimum what companies shall provide to legitimately stay with successful business in especially in a rural environment when the companies of the oil industry are generally operating [8].

In the oil and gas sector, CSR activities represent an attempt to fill that void. It is no secret that many oil-rich nations have been poorly governed, and the international oil companies have extracted valuable resources from such countries in the past, while paying inadequate attention to the attendant environmental and social costs states Spence, in his paper [41]. His study shows that there are no boundaries of CSR, such as cultural, racial and etc., the danger everywhere is the same, namely, the giant multinational companies producing annual CSR reports showing their active involvement in the regions, but how they operate practically in the local business can be said different. The TCO case also represents many special characteristics from both sides of CSR operations. The recommendation of the paper is serving the objective: the dark side of CSR should remain only as a threat that should be avoided. The author from Nigeria of a very new research paper enforces the joint activities of academic people and business men to design a new model which will be applicable within any circumstances and to different developing countries [22].

Organizations around the world and their stakeholders, are becoming increasingly aware of the need for and benefits of socially responsible behaviour. The objective of social responsibility is to contribute to sustainable development. It is important that local authorities create non-governmental organizations that work for the interests of the community. It is important that they know exactly the problematic areas and act accordingly. These agencies will be responsible and also produce different kinds of CSR reports which will consist of the study of the required necessities and the proper distribution of the resources, donations received from companies for the benefits of common goals of community development. 


\section{Limitations and Further Research}

The result of this paper was based on the overview of relevant CSR literature and on a field study at a joint venture transnational petroleum company in Atyrau Oblast in Kazakhstan, the TCO. Any efforts to draw general conclusions on this very delicate management and social topic are premature. The further research as a subject of a PhD dissertation will be put into a broader social perspective. The investagation of social influence of these multinationals on community and its development means more than an empathic discussion on social responsibilities of corporations. Without the understanding of policy makers' interests (both local and on government level) further steps of research can not offer generalized findings for the Kazakh Oil and Gas Industry. A benchmarking profile will follow as the next phase of the research. Benchmaring is a constant and systematic process for gaining results of the total industry. This first study - as a pilot case offers a good direction to clarify the real objective of an industry level research.

\section{Special thanks}

Special thanks are due to managers of TCO who were very helpful in providing information regarding CSR practice and reports, to Professor Ferenc Farkas at University of Pécs Faculty of Business and Economics for his help as External Consultant, and to the Director of the Graduate Programme at Abai Kazakh Natonal Pedagogical University Gulmira B. Nurlihina for supporting and sponsoring this study.

\section{References}

[1] A Dictionary for Petroleum Industry. Second edition. The University of Texas at Austin (2007)

[2] Amagoh, F.; Kabdiyeva,A.: Management Issues for Improving NCO Sustainability in Kazakhstan. World Journal of Social Sciences (2012), Vol. 3, May 2012, pp. 31-40

[3] Ásványi, K.: CSR-marketingmix a gyakorlatban. Marketing \& Menedzsment. The Hungarian Journal of Marketing and Management (2012), XLVI. évf. 3. sz. 32-41. o.

[4] Baghi, I; Rubaltelli, E.; Tedeschi, M.: A Strategy to Communicate Corporate Social Responsibility: Cause Related Marketing and its Dark Side, Corporate Social Responsibility and Environmental Management (2008) 16, 15-26

[5] Belal, A. R.: Corporate Social Responsibility reporting in developing countries: the case of Bangladesh, Aldershot England Burlington Vt. Ashgate (2008)

[6] Bertoil, A., A.; Sobczak, A.: "Endogenous and Exogenous Factors for Change in Concept and Practice of Corporate Social Responsibility, Corporate Citizenship and the Politics of Stakeholder Influence: Learning 
from the Case of France, EGOS Annual Conference (2004) Ljubljana, Slovenia, July

[7] Bird, F.; Smucker, J.: The Social Responsibility of International Business Firms in Developing Areas. Journal of Business Ethics (2007) 73:1-9

[8] Bowler, I. R. ; Bryent, C. R.; Cocklin, Ch.: The Sustainability of Rural Systems: Geographical Interpretations (2002) Dordrecht; Boston: Kluwer Academic Publishers 280 p.

[9] Brudnay, J ; Nezhina, T.: "What is Old is New Again. Achieving Effectiveness with Volunteer Programs in Kazakhstan.", Voluntas: International Journal of Voluntary and Non-profit Organizations (2005) Vol. 16, No. 3, pp. 293-308

[10] Burkitt, B.; Ashton, F.: The Birth of Stakeholder Society. Critical Social Policy (1996) Vol. 16, No. 49, 3-16

[11] Cowper-Smith, A.; de Grostois, D.: The Adaptation of Corporate Social Responsibility Practices in the Airline Industry. Journal of Sustainable Tourism (2011) Vol. 19, No. 1, 59-77

[12] Dobrai, K.; Farkas, F.: „Professional Business Organizationals Meeting the Challenges of a Changing Business Environment", International Journal of Knowledge, Culture and Change Management (2007) Vol. 7, No. 3, pp. 7384

[13] Egemberdiyeva, S. M.: Tendency of Development of the World Petroleum Market in Terms of Globalization (2010) Eurasian National University Journal of L.N. Gumilev - No. (73) 247-252

[14] Ghosal, S.: "Bad Management Theories are Destroying Good Management Practice", Academy of Management Learning \& Education (2005), 4, 1, $75-91$

[15] Gomm, R.; Hammersley, M.; Foster, P. (ed.): Case Study Method. (2000), Sage Publications Ltd.

[16] Grajzi, P.; Murrell, P.: Fostering civil society to build institutions. Why and when?, Economics of Transition (2009), Vol. 17 Issue. 1, 1-14 pp.

[17] Guenther, E.; Hoppe, H.; Poser, C.: Environmental Corporate Social Responsibility of Firms in the Mining and Oil and Gas Industries: Current Status Quo of Reporting Following GRI Guidelines, Greener Management International (2007), Issue. 53, 7-25. pp.

[18] Haufler, V.: "Corporate Transparency: International Diffusion of a Policy Idea?”, University in Maryland Workshop Paper (2006)

[19] Hutchins, M., J.; Walck, C.,L.; Sterk, P., D.; Campbell, G., A.: Corporate Social Responsibility. A Unifying Discourse for the Mining Industry. Grener Publishing Ltd. (2007), pp. 17-30 
[20] Idemudia, U.: Corporate social responsibility and developing countries: moving the critical CSR research agenda in Africa forward, Progress in Development Studies (2011), Vol. 11 Issue. 1, 1-18. pp.

[21] Ite, U.E.: Partnering with the state for sustainable development: Shell's experience in the Niger Delta, Nigeria Nigeria Sustainable Development (2007), Vol.15 Issue. 4, 216-228. pp.

[22] Kiikpoye, K. A.: New corporate social responsibility models for Oil Company in Nigeria's delta region: What challenges for sustainability?, Progress in Development Studies (2012), Vol. 12 Issue. 4, 259-273. pp.

[23] Koleva, P.; Rodet-Krichvili, N.; David, P.; Marasova, J.: Is corporate social responsibility the privilege of developed market economies? Some evidence from Central and Eastern Europe, The International Journal of Human Resource Management (2010), Vol 21., No.2, 274-293

[24] Kotler, P.; Lee, N.: Corporate Social Responsibility. John Wiley and Sons Inc. Hungarian Edition: A vállalatok társadalmi felelösségvállalása. HVG Kiadó Budapest (2007)

[25] KPMG: International Survey of Corporate responsibility Reporting (2005), Amsterdam: KPMG

[26] Kumar, R.; Markeset,T.: Development of performance-based service for the oil and gas industry: a case study, Journal of Business \& Industrial Marketing (2007), Volume 22 issue 4. 272-280

[27] Lee, J.: NGOs in Kazakhstan \& Caspian See Region: an Overview. Centre for Applied Studies in International Negotiations. Geneve, Switzerland (2007) 31.pp.

[28] Lehtimaki, H.; Kujala, J.; Heikkinen, A.: Corporate Responsibility in Communication: Empirical Analysis of Press Releases in a Conflict, Business Communication Quarterly (2011), Volume 24, Number 4, December 432-449

[29] Lindberg, Y.: "The Global CSR agenda: implications for Kazakhstan” How can CSR performance be improved in Kazakhstan?, Central Asian Studies Centre Panel debate co-organized with SIGLA, 1. March (2012)

[30] Makhmutova, M.; Akhmetova, A.: Civil Society in Kazakhstan (2011), Civicus, Almaty

[31] Martinez, E. O.; Crowther, D.: Is disclosure the right way to comply with stakeholders? The Shell Case, Business Ethics (2008), Vol. 17 Issue. 1, 1322. pp.

[32] Matos, S.; Hall, J.: Integrating sustainable development in the supply chain: The case of life cycle assessment in oil and gas and agriculture biotechnology, Journal of Operations Management (2007), Volume 25, Issue 6, 1053-1102 
[33] McWilliams, A.: Siegel, D.: Corporate social responsibility. A theory of the firm perspective, Academy of Management Review (2001), 26, 117-127

[34] Morsing, M.: Strategic CSR communication: The challenge of telling others how good you are, Berlin. Germany: Springer Verlag M. De Witte \& Jonker, J. (Eds.) Management models for CSR: A comprehensive overview (2006), 237-245. pp.

[35] Official "Tengizchevroil" site www.tengizchevroil.com (03.04.2013)

[36] Porter, M.E.: Kramer, M.R.: Strategy and society: The link between competitive advantage and corporate social responsibility, Harvard Business Review (2006), 84 (12), 78-92

[37] Prasad, A.: CSR as nash Equlibrium, Journal of Management Research (2005), Vol. 5 Issue. 2, 59-71. pp.

[38] Prepared by: Ettenbotough, M.; Shyne, J.: World Bank Report. Corporate Social Responsibility Public Policy and the Oil Industry in Angola, Boston USA (2003), 19. pp.

[39] Report on TCO's CSR activities. www.csrkz.org (02.03.2013)

[40] Saltmarshe, D.: Civil society and sustainable development in Central Asia, Central Asian Survey (1996), Vol. 15 Issue. 3-4, 387-398. pp.

[41] Spence, D., B.: "Corporate social responsibility in the oil and gas industry: the importance of reputational risk"(2011), Chicago-Kent Law Review Volume 86:1

[42] Stake, R. E.: The Case Study Method in Social Inquiry. Educational Researcher (1978), Vol. 7. No. 2. pp. 5-12

[43] Strategic development plan of Ministry of oil and gas of Kazakhstan for 2011-2015. Astana, 2009

[44] Tippee, B.: „Where is the shortage? A nontechnical guide to petroleum economics". PennWell Publishing Company 1993

[45] Tsalik, S.; Ebel, R.: Caspian Oil Windfalls: Who Will Benefit?, Caspian Revenue Watch Open Society Institute (2003), 215. pp.

[46] Tuodolo, F.: Corporate Social Responsibility Between Civil Society and the Oil Industry in the Developing World, ACME: In International E-Journal for Critical Geographies (2009), Vol. 8 Issue. 3, 530-541. pp.

[47] Valenta, M.;Crane, A.: Public responsibility and Private Enterprise in Developing Countries, California Management Review (2010) Vol. 52 Issue. 3, 52-78. pp.

[48] Verboven, H.: Communicating CSR and Business Identity in the Chemical Industry Through Mission Slogens, Business Communication Quarterly (2011), Vol. 74 Issue 4, 415-431. pp. 
[49] Watts, M. J.: Righteous Oil?, Human Rights the Oil Complex and Corporate Social Responsibility Annual Reviews Environment Resources (2005), Vol. 30 Issue. 9, 373-407. pp.

[50] Wikipedia materials on Kazakhstan www.wikipedia.org (05.04.2013)

[51] World Trade Organization (WTO), White Paper Corporate Social Responsibility (CSR) in Kazakhstan, (2012), 11. pp.

[52] Yerkebulanov, Y.; Saginova, D.: "Kazakhstani Content in Procurement of Subsoil Users", Kazakhstan International Business Magazine (2011), Issue. 5. 3-6. pp

[53] Zarsky, L.: "Human Rights and the Environment. Conflicts and norms in a globalizing world.” (2002) London: Earthscan Publishing LTD.

[54] Zhumaly R., "Running a spiral: the history of Kazakh oil". Exclusive 2009 No. 90 